\title{
Berbelanja Melalui Jasa Titip Perabot di Masa Pandemi Covid-19: Studi Kasus @jastipbyarumi
}

\author{
Musdalifa Tul Jannah \\ Universitas Hasanuddin \\ musdalifatuljannah.99@gmail.com
}

\begin{abstract}
In the digital era, deposit service (jastip) which were previously carried out offline, are now also developing and can be done by online and become a very promising business. In Indonesia, the term jastip by shopping online is starting to be widely known by the wider community, especially for those who use social media, such as Facebook. This business benefits from a predetermined additional fee for each consumer ordered goods, so those who order goods do not need to go to the store to buy goods or leave the house. Buying goods online through jastip has become increasingly popular during the Covid-19 pandemic, especially since the government launched large-scale social restrictions (PSBB) that limit people's mobility.
\end{abstract}

This research was conducted on social media, namely Facebook on jastip providers and consumers based on observations on social media, such as Facebook, which showed the widespread purchase of goods through jastip among women in Bulukumba Regency. There are them women involved in this study. Thye are varied based on age (between 23 and 40 years), occupation (five housewives, four entrepreneurs, and jastip provider), and status (nine buyers and a jastip provider).

The study indicate that the phenomenon of jastip is a business model that has the potential to be developed which is supported by technological developments, and social media is used as a means to sell by online with jastip services. The existence of jastip services during the Covid-19 pandemic is very beneficial for both the jastip provider and the consumers. Products offered by Informa are posted through Facebook by jastip provider. Among other jastip items offered on Facebook, home furnishings (sofa, dining table, patio chairs, etc.) are the most popular items. Model, status display, price, and quality are four main reasons why women choose Informa's jastip products, especially during this Covid-19 pandemic. The reason for the jastip provider (@jastipbyarumi) presenting the Informa product jastip service is because women in Bulukumba Regency love to shop online, so they are seen as a business opportunity, satisfying their hobbies, and as a source of income. In promoting jastip services, the strategy used by jastip providers is to continue to provide store discount prices, upload products in stories, and open social gathering lots. Dealing with this service business, the main capital is not only money, butmore importantly trust, perseverance, and ethics in running this business. The increase in the use of jastip during the Covid-19 pandemic is intertwined with an increase in turnover of jastip.

Keywords: Jastip, business, social media, Covid-19, pandemic, Informa, and turnover.

\section{Pendahuluan}

Menurut Wikipedia, Virus Corona atau sering disebut juga Covid-19 (Corona Virus Disease 2019) merupakan virus menular yang bisa menyebabkan kematian jika sistem imun manusia lemah. Pada bulan Maret 2020 lalu,
Covid-19 telah dinyatakan masuk ke Indonesia dan sejaka Covid-19 mewabah di Indonesia, ini menyebabkan perekonomian terganggu karena dengan kebijakan pembatasan sosial berskala besar (PSBB) oleh pemerintah menyebabkan mobilitas masyarakat dibatasi, 
sehingga mengganggu aktivitas rutin masyarakat, seperti aktivitas pedagang pasar, mall, perhotelan, restauran, wisata, pembangunan infrastruktur, wedding organizer, dll. ${ }^{1}$ Pandemi Covid-19 tidak hanya menimbulkan dampak yang horor, namun juga dapat memberi pengaruh positif terhadap perekonomian Indonesia, di antaranya adalah pebisnis online yang dapat dimanfaatkan sebagai koreksi agar investasi dapat stabil walaupun ekonomi global sedang terancam (Nasution dkk. 2020:215).

Dewasa ini begitu maraknya berbagai macam jenis bisnis online yang muncul membuat teknologi dalam transaksi jual-beli juga semakin canggih. Keterbatasan waktu yang dimiliki konsumen untuk dapat berbelanja secara konvensional, karena kesibukan, kondisi jalan yang sangat ramai, hingga terjadi kemacetan menyebabkan timbulnya keinginan konsumen untuk dapat berbelanja dengan mudah dan cepat (Wariati dan Nani 2014:2).

Berdasarkan laporan terbaru We Are Social, pengguna Internet di Indonesia sebanyak 175,4 juta pada Januari 2020 . Ini meningkat 25 juta (17\%) dari tahun 2019. Penetrasi internet di Indonesia mencapai 64\% pada Januari 2020. Pengguna media sosial di Indonesia sebanyak 160 juta pada Januari 2020. Ini meningkat 12 juta $(8,1 \%)$ antara April 2019 dan Januari 2020. Penetrasi media sosial di Indonesia mencapai 59\% pada Januari $2020{ }^{2}$

Jika merujuk pada survei internet Asosiasi Penyelenggara Jasa Internet Indonesia (APJII) 2019-2020, maka 48\% dari 88,1 juta orang pengguna internet itu merupakan masyarakat pengonsumsi internet harian. ${ }^{3}$ Artinya, warga Indonesia tidak bisa lepas dari gadget dan internet setiap harinya. Hal inilah yang kemudian dimanfaatkan oleh pelaku

\footnotetext{
${ }^{1}$ https://en.m.wikipedia.org/wiki/COVID19 pandemic, diakses tanggal 28 Mei 2021.

${ }^{2} \mathrm{https}$ ://andi.link/hootsuite-we-are-socialindonesian-digital-report2020/\#: :text=Hootsuite\%20(We\%20are\%20Social
}

usaha untuk membuka bisnis online, dan media sosial menjadi wadah untuk menawarkan produk yang diperjualbelikan. Dari media sosial, respon langsung atas penjualan tersebut dapat diketahui dan dapat menarik perhatian orang untuk berbelanja secara online.

Salah satu media sosial yang populer adalah aplikasi Facebook. Facebook adalah aplikasi yang sangat laris bagi pengguna media sosial pada saat peluncurannya di tahun 2014 dan terus bertambah di setiap tahunnya. Facebook sendiri adalah layanan berbasis internet sekaligus jejaring sosial untuk berbagi cerita via gambar digital. Para pengguna gadget kerap kali menggunakan jejaring sosial ini untuk langsung berbagi hasil jepretan mereka. Oleh karenanya, kebanyakan pebisnis online memilih untuk mempromosikan barangnya melalui aplikasi Facebook. Mengapa Facebook? Karena hampir semua kalangan menggunakan Facebook mulai dari anak-anak, remaja, dewasa hingga orang tua menggunakan media sosial tersebut. Facebook sendiri lebih mudah digunakan bagi kalangan orang tua dibandingkan dengan aplikasi lain.

Kehadiran layanan jastip ini cukup membantu para konsumen karena mereka tidak lagi harus mengunjungi toko yang menjual barang, menghindari antrian panjang yang biasanya terjadi selama musim penjualan. Konsumen dapat duduk dan bersantai, menggunakan smartphone dan memesan produk yang mereka inginkan (Muslicha dan Irwansyah 2019:152).

Sistem jastip ini sebenarnya sudah ada sejak lama dan dikenal dengan istilah "ongkos jalan”. Namun, menurut Rizki (2020:67), pada sekitar tahun 2016 fenomena jastip yang kekinian mulai muncul di tanah air. Ini menjadi peluang bisnis baru yang kini tengah

\%20secara,pada $\% 20$ bulan $\% 20$ kedua $\% 20$ setiap $\% 2$ Otahunnya, diakses tanggal 12 Maret 2021.

${ }^{3} \mathrm{https}$ ://apjii.or.id/survei, diakses tanggal 12 Maret 2021. 
menjamur. Oleh karena itu, banyak orang ingin mencoba usaha ini. Bisnis ini pada dasarnya terjadi karena dipicu oleh perkembangan media sosial yang semakin pesat.

Survei yang dilakukan oleh Jakpat Survey Report (2017:5) menunjukkan bahwa kesadaran responden terhadap jastip cukup tinggi. Lebih dari separuh panel telah mengetahui tentang keberadaan layanan jastip. Selain itu, kesadaran layanan jastip tidak dibatasi oleh jenis kelamin, usia, atau lokasi. Penyedia layanan jastip-pun dapat melakukan bisnisnya kapanpun dan dimanapun asalkan selalu update barang jualannya melalui media sosial. ${ }^{4}$

Bisnis jastip menjadi peluang usaha yang menarik dan biasanya dilakukan oleh seseorang yang tengah melakukan travelling, baik di dalam negeri maupun luar negeri. Munculnya pelaku bisnis jastip ini berawal dari seseorang yang sedang melakukan perjalanan, lalu melakukan pembelian produk titipan. Lambat laun kegiatan titip-menitip ini menjadi peluang bisnis yang bernilai ekonomi. Polemik bisnis jastip timbul karena menyangkut produk-produk impor luar negeri. Para pelaku jastip pada awalnya hanya memotret dan memosting beberapa foto brand terkenal di akun media sosial, seperti Facebook mereka dan menginformasikan spesifikasi dari barang tersebut. Biasanya besarnya biaya jasa sudah diinformasikan sejak awal, dan terpisah dengan harga produk. Omset yang diperoleh dari bisnis ini bisa beragam mulai dari ratusan ribu sampai puluhan juta rupiah per bulan (Rizki 2020:47).

Namun, layanan jastip bukan tanpa perdebatan. Jastip dalam pandangan Islam menurut studi Eliza (2018) menunjukkan bahwa pelaku jastip rentan terhadap penyalahgunaan, mulai dari tidak adanya kontrak dan perjanjian yang mengikat antara konsumen dan pelaku bisnis jastip, sehingga

\footnotetext{
${ }^{4}$ https://blog.jakpat.net/jastip-jasa-titip-shoppingentrusted-goods-service-survey-report/, diakses tanggal 2 Februari 2021.
}

permainan harga potensil terjadi di luar dari upah sebagai jasa. Hal tersebut dapat menyebabkan tidak dipenuhinya rukun dan syarat dari samsarah (perantara pergdagangan), akad dalam jual-beli menjadi batal karena objek yang diperjual belikan merupakan barang milik orang lain.

Studi Sari (2019) mengidentifikasikan bahwa jikapun ada perjanjian antara pembeli dan pelaku jastip, praktik jual-beli online belum terlaksana dengan baik karena adanya ketentuan di luar kesepakatan awal yang dilakukan oleh pihak penyedia secara sepihak ketika barang yang dipesan oleh pembeli tidak ada, maka uang atas jasa tetap diambil sebagian. Menurut fikih muamalah, praktik tersebut belum memenuhi salah satu syarat ijarah (pemindahan hak guna), maupun ketentuan ujrah (imbalan yang harus dibayar oleh sang pemberi kuasa pembiayaan). Dalam praktiknya, jika ada pihak yang merasa keberatan, maka akad yang dilakukan tidak sah. Namun kajian Dezella (2020) menunjukkan bahwa praktik bisnis jastip yang dilakukan oleh generasi millenial di Sidoarjo menemukan bahwa praktik tersebut telah memenuhi prinsip-prinsip bisnis dalam Islam, yakni customer oriented, persaingan yang sehat, transparansi dan prinsip keadilan. Praktik bisnis jastip yang dilakukan generasi milenial di Sidoarjo juga telah memenuhi syarat-syarat sebagaimana yang dikemukakan oleh ulama kalangan Malikiyyah (mazhab fikih dalam Islam yang masih bertahan hingga hari ini) dan Hambaliah (mazhab yang saat ini dianut di Arab Saudi).

Meskipun demikian, pemesanan barang melalui jastip secara online tetap dianggap berpotensi merugikan pihak konsumen jika pemesanan tiba dengan cacat. Ini mengindikasikan pentingnya perlindungan konsumen. Ada dua upaya perlindungan 
hukum, yakni perlindungan hukum preventif dan represif. Ketentuan Pasal 4C UndangUndang No.8 Tahun 1999 Tentang Perlindungan Konsumen yang meliputi hak-hak konsumen, kewajiban, larangan-larangan pelaku usaha. Tanggung jawab pelaku usaha, yaitu berupa product liability (tanggung gugat produk), yaitu tanggung jawab secara hukum dari orang/badan yang menghasilkan suatu produk. Dalam konteks ini, produsen harus bertanggung jawab atas kecacatan produk yang diterima oleh konsumen (Mahesti dan Gusti 2019).

Sejumlah literatur tentang jastip dan media sosial telah ada, Putu dan Agus (2019) menunjukkan adanya korelasi antara penggunaan media sosial dengan raihan penjualan yang diperoleh UKM. Dari empat media sosial yang digunakan, yakni Facebook, Twitter, Instagram dan Youtube ternyata Instagram berperan dominan dalam meningkatkan penjualan produk UKM. Dalam konteks jastip, Studi Rizki (2019) mengidentifikasi, bahwa komunikasi yang terjalin antara penyedia jastip dan konsumen adalah melalui media sosial Instagram saat melakukan transaksi. Ini berkelindan dengan temuan Putra (2018) yang mengindikasikan efektifitasnya penggunaan Instagram sebagai media pemasaran dan media untuk memengaruhi prilaku konsumen. Menurut Muslicha dan Irwansyah (2019), fitur-fitur Instagram yang menarik, seperti unggahan foto, Instastory, dan jangkauannya yang tak terbatas pada kalangan tertentu membuat bisnis jastip melalui Instagram ini menarik perhatian konsumen dan sangat potensil untuk berkembang. Ini menunjukkan bahwa media sosial telah menjadi alat komunikasi dalam berbisnis di era digital ini.

Pada masa pandemi Covid-19 ini, model bisnis yang menggunakan teknologi digital dengan memanfaatkan media sosial tidak saja sangat efektif, tapi juga aman dalam memasarkan produk kepada para konsumen.
Ini didukung oleh kebijakan pemerintah dengan menerbitkan POJK Nomor 11/POJK.03/2020 tentang stimulasi Perekonomian Nasional sebagai Kebijakan Countercyclical Dampak Penyebaran Coronavirus Disease 2019 (Mahriani 2020).

Diskusi dalam penelitian ini dimulai dengan membahas tentang bagaimana belanja online dalam kaitan media sosial, dan jastip. Ini diikuti dengan pembahasan tentang bagaimana konsumen berkenalan dengan Informa sebagai peritel yang sangat populer di kalangan ibu-ibu. Pembahasan berikutnya terfokus pada kenapa ibu-ibu menjadikan produk Informa sebagai pilihan. Ini dilanjutkan dengan mendemonstrasikan eksistensi penyedia layanan jastip dalam berbelanja pembelian produk. Pada bagian akhir diskusi dititikberatkan pada bagaimana signifikannya peningkatan omzet penyedia layanan jastip di masa pandemi Covid-19.

\section{Metode Penelitian}

Penelitian ini dilakukan di media sosial, yaitu Facebook yang menunjukkan maraknya pembelian barang melalui jastip di kalangan ibu-ibu di Kabupaten Bulukumba. Di Kabupaten Bulukumba, pelaku jastip lebih dominan memilih menggunakan media sosial Facebook untuk jual-beli perabot rumah tangga karena ibu-ibu lebih cenderung menggunakan aplikasi Facebook dibandingkan media sosial lainnya untuk berselancar di dunia maya dan untuk membeli barang. Informa dipilih karena ini merupakan toko yang menjual perabot rumah tangga dan memiliki banyak peminat karena perabot Informa dianggap sebagai perabot "berkelas" bagi masyarakat Bulukumba.

Informan dalam penelitian ini adalah ibi-ibu pembeli barang melalui penyedia layanan jastip. Perempuan dipilih karena berdasarkan observasi di Facebook, perempuan yang banyak berbelanja perabot. Selain itu, perempuan secara umum 
diidentikkan dengan sosok penggemar shopping (Elfin dan Yusuf 2019). Informan yang berpartisipasi dalam penelitian ini berjumlah sepuluh orang yang bervariasi berdasarkan umur (antara 23 dan 40 tahun), pekerjaan (lima orang ibu rumah tangga, empat orang wiraswasta, dan seorang penyedia layanan jastip), dan status (sembilan orang pengguna dan seorang penyedia jastip), sebagaimana dijabarkan pada Tabel 1 berikut:

\begin{tabular}{|c|c|c|c|}
\hline \multicolumn{4}{|c|}{ Tabel 1. Informan Penelitian } \\
\hline No. & Nama & Umur (Tahun) & Pekerjaan/Status \\
\hline 1. & Ulfa & 23 & $\begin{array}{l}\text { Ibu rumah tangga/pengguna layanan } \\
\text { jastip }\end{array}$ \\
\hline 2. & Fasihah & 25 & $\begin{array}{l}\text { Ibu rumah tangga/ pengguna layanan } \\
\text { jastip }\end{array}$ \\
\hline 3. & Umrah & 40 & $\begin{array}{c}\text { Ibu rumah tangga/ pengguna layanan } \\
\text { jastip }\end{array}$ \\
\hline 4. & Dinda & 30 & $\begin{array}{l}\text { Ibu rumah tangga/ pengguna layanan } \\
\text { jastip }\end{array}$ \\
\hline 5. & Dian & 24 & $\begin{array}{l}\text { Ibu rumah tangga/ pengguna layanan } \\
\text { jastip }\end{array}$ \\
\hline 6. & Sri & 27 & Wiraswasta/ pengguna layanan jastip \\
\hline 7. & Darmi & 40 & Wiraswasta/ pengguna layanan jastip \\
\hline 8. & Nirfawati & 39 & Wiraswasta/ pengguna layanan jastip \\
\hline 9. & Purnama & 30 & Wiraswasta/ pengguna layanan jastip \\
\hline 10. & Umi & 23 & Owner/Admin @jastipbyarumi \\
\hline
\end{tabular}

Teknik pengumpulan data yang digunakan dalam penelitian ini yaitu pengamatan (observation) dan wawancara (indepth interview). Observasi dilakukan pada akun-akun jastip di Facebook dengan mengidentifikasi aktivitas-aktivitas akun-akun penyedia layanan jastip. Wawancara dilakukan dengan topik-topik wawancara yang mencakup aktivitas jual-beli di Facebook, pengelolaan akun, alur jual-beli, jenis-jenis barang yang diperjual-belikan sebagai item barang jastip.

Proses analisis data dilakukan dengan mengumpulkan seluruh data yang diperoleh dari transkrip hasil wawancara dan catatan observasi. Setelah membaca transkrip dan catatan tersebut, maka dilakukan pengelompokan, yaitu: jastip, produk informan, alasan memilihnya, proses layanan jastip, dan omzet.

Izin penelitian diperoleh melalui universitas. Selanjutnya, surat perizinan diteruskan ke Kantor Daerah Bulukumba karena penelitian ini dilakukan pada masyarakat Kabupaten Bulukumba. Kemudian meminta kesediaan calon informan untuk terlibat dalam penelitian. Mereka dihubungi melalui pesan singkat, dan chat personal di WhatsApp atau Messenger di Facebook dengan terlebih dahulu menjelaskan tentang identitas diri, topik, tujuan, teknis pelaksanaan dan manfaat dari penelitian yang dilakukan. Jika mendapatkan persetujuan dari yang bersangkutan, maka masing-masing dimintai kesediannya untuk diwawancarai dan direkam. 
Lalu dilanjutkan dengan mengatur waktu dan tempat wawancara sesuai kesepakatan bersama. Dalam proses penyusunan data penelitian. Mereka dimintai persetujuan terkait dengan nama informan dan nama akun. Hal tersebut dilakukan untuk memroteksi privasi dan identitas informan. Semua informan menyetujui untuk digunakan nama diri dan nama akun yang asli penyedia layanan jastip.

\section{Belanja Online, Facebook, dan Jastip}

Belanja online pertama kali ditemukan oleh Michael Aldrich pada tahun 1979, hingga pada akhirnya berkembang pesat sampai sekarang (Tjiptono, 2012:10). Belanja online adalah sebuah teknologi yang berkaitan dengan jualbeli suatu produk atau jasa, melalui sebuah sistem elektronik seperti internet atau jaringan komputer lainnya. Belanja online merupakan salah satu kemudahan dalam gaya hidup masyarakat moderen yang bisa dicapai melalui internet. Selain itu, perusahaan/distributor maupun konsumen merasa sangat diuntungkan dengan belanja online.

Dari sisi perusahaan, ini akan mempermudah dalam melakukan pemasaran terhadap produk yang diperjualbelikan, mempermudah komunikasi dengan pelanggan, serta menurunkan biaya operasional perusahaan. Sedangkan keuntungan dari sisi konsumen dapat mempermudah mereka dalam memenuhi kebutuhan, seperti membeli produk-produk yang sulit diperoleh di wilayahnya, lebih fleksibel karena dapat bertransaksi dimanapun konsumen berada, dan ada banyak keuntungan lainnya. Berbelanja secara online telah menjadi alternatif untuk melakukan pembelian barang ataupun jasa bagi para konsumen. Penjualan secara online juga semakin berkembang, baik itu dari segi pelayanan, efektifitas, keamanan,

\footnotetext{
${ }^{5}$ https://money.kompas.com/read/2020/10/27/13584
} 7026/aktivitas-belanja-online-meningkat-drastis- maupun popularitas (Laohapensang, 2009:508).

Belanja online telah menjadi bagian dari kegiatan belanja masyarakat, melalui media sosial, seperti, Facebook, Instagram, dll. dengan berbagai kenyamanan belanja. Aplikasi Facebook adalah aplikasi yang sangat laris bagi pengguna media sosial pada saat peluncurannya di tahun 2014 dan terus bertambah di setiap tahunnya. Facebook sendiri adalah layanan berbasis internet sekaligus jejaring sosial untuk berbagi cerita dan gambar digital. Para pengguna gadget kerap kali menggunakan jejaring sosial ini untuk langsung berbagi hasil jepretan mereka. Oleh karenanya, kebanyakan pebisnis online memilih untuk mempromosikan barangnya melalui aplikasi Facebook.

Pebisnis online baru-baru ini mengalami kenaikan drastis selama masa pandemi Covid-19. Berdasarkan survey yang dilakukan oleh Redseer, 51\% responden mengaku pertama kali menggunakan aplikasi belanja saat pembatasan sosial berskala besar (PSBB). Ini membuat jumlah permintaan di $e$ commerce pun melonjak secara signifikan, yakni antara 5-10 kali dibandingkan sebelum pandemi Covid-19 (Pusparisa, 2020). Ini karena masyarakat Indonesia yang mengikuti aturan pemerintah untuk "dirumah aja" dan dituntut untuk menghindari tempat keramaian menjadikan pergerakan masyarakat menjadi terbatas. Oleh karenanya, untuk memenuhi kebutuhan, masyarakat cenderung memilih berbelanja secara online. ${ }^{5}$

Menurut data Indonesia E-commerce Association (IdEA) dan We Are Social, belanja online di Indonesia mengalami peningkatan sebanyak $25 \%$ hingga $30 \%$ selama masa pandemi Covid-19. Masyarakat yang lebih banyak beraktivitas di rumah mendorong peningkatan pada kategori rumah tangga yang

ini-sebabnya amp $=1$ \&page $=2$, diakses tanggal 27 April 2021. 
mencapai lebih dari dua kali lipat dibandingkan dengan periode sebelum pandemi. ${ }^{6}$

Menjamurnya sistem belanja online meunculkan peluang bisnis baru yang salah satunya oleh masyarakat dikenal sebagai jasa titip (disingkat jastip). Jastip adalah pekerjaan keluar masuk toko, mall atau pedagang besar dengan beberapa merek (brand) tertentu sesuai dengan keinginan para pelanggan yang memercayakan pada jasa mereka untuk membeli barang yang diinginkan. Barang yang dicari tidak hanya di dalam negeri, tapi juga dari luar negeri. ${ }^{7}$ Jastip dapat diartikan secara umum sebagai suatu peluang atau layanan usaha untuk membelikan barang pesanan yang diminta oleh pengguna jasa dengan memanfaatkan teknologi atau media sosial untuk pemasarannya (Muchtar, 2019:134).

Jastip menjadi fenomena yang tersebar luas karena ini merupakan layanan informal yang menawarkan bantuan kepada orangorang yang membutuhkan atau ingin membeli sesuatu tetapi tidak dapat pergi ke tempat yang diinginkan untuk membeli sendiri karena berbagai alasan. Semakin banyak individu atau perusahaan yang menawarkan layanan jastip, maka semakin baik bagi pembeli karena mereka tidak harus mengunjungi toko yang menjual barang, dan juga menghindari antrian panjang yang biasanya terjadi selama musim penjualan. Pembeli tinggal bersantai dirumah tanpa harus datang langsung ke toko, mereka hanya menggunakan smartphone dan memesan produk yang diinginkan (Muslicha dan Irwansyah, 2020:144).

Menurut Mahesti dan Gusti (2019:7), dengan adanya kemudahan dalam proses jualbeli barang dengan sistem jastip melalui media

6 https://bisnis.tempo.co/amp/1404513/ideakenaikan-penjualan-e-commerce-25-persen-selamapandemi, diakses tanggal 27 April 2021. sosial, ini memberikan keuntungan bagi pihak konsumen untuk mendapatkan barang sesuai dengan keinginan tanpa harus mengeluarkan biaya dan tenaga ekstra untuk mencari barang yang diinginkan.

Pembayaran layanan jastip dapat dilakukan dengan membayar masing-masing item, atau akumulasi dari semua transaksi. Namun, survei yang dilakukan Jakpat Survey Report (2017:10) menunjukkan bahwa ada dua macam jastip, yakni jastip per item dan jastip total transaksi. Dari 1.603 responden dalam survei tersebut, ada $58 \%$ responden yang cenderung membayar layanan jastip berdasarkan total transaksi. ${ }^{8}$

Melalui media sosial para penyedia jastip menawarkan berbagai barang untuk dapat dibeli melalui jasa mereka. Diasumsikan bahwa sebelum berbelanja melalui jastip, para konsumen dapat melakukan window shopping terlebih dahulu melalui media sosial sebelum akhirnya memutuskan untuk membeli barang yang diinginkan atau dibutuhkan. Melalui jastip konsumen tidak perlu keluar rumah, meskipun harus mengeluarkan biaya tambahan untuk jastip. Namun, ini jauh "lebih murah" dibandingkan dengan biaya finansial, fisik, dan psikologis yang harus ditanggung jika yang bersangkutan pergi berbelanja secara langsung.

Ketika kebijakan PSBB mulai diberlakukan, banyak toko dan restoran yang mulai membatasi jam operasi, dari pusat perbelanjaan, toko retail, hingga restoran mulai mengurangi aktivitas mereka. Hal ini bak angin segar bagi penyedia layanan jastip karena mereka yang berjiwa bisnis. Tren belanja melalui jastip perlahan jadi kebiasaan baru selama pandemi, termasuk bagi para ibu-

\footnotetext{
7 https://koran.bisnis.com/m/read/20170614/432/662 322/jasa-titip, diakses tanggal 18 Februari 2021. $8 \mathrm{https}$ ://blog.jakpat.net/jastip-jasa-titip-shoppingentrusted-goods-service-survey-report/, diakses tanggal 2 Februari 2021.
} 
ibu. Pandemi Covid-19 berhasil mempercepat transformasi bisnis serta aktivitas jual beli dari tradisional menjadi daring.

\section{Berkenalan Dengan Informa}

Informa Innovative Furnishings (selanjutnya disingkat Informa) merupakan salah satu ritel terbesar di Indonesia, yang berpusat di kota Jakarta dan memiliki kantor cabang di berbagai Kota Besar di Indonesia, termasuk Kota Makassar. Selain itu, Informa memiliki keunggulan dari segi model dan keragaman yang dapat mengilhami penataan disain rumah mereka. Bagaimana mereka mengenal Informa cukup beragam, yakni dari tetangga, teman, dan Facebook.

Ulfa (23 tahun), awalnya ia mengetahui tentang Informa karena ada tetangga mereka yang membeli kursi teras dan modelnya kelihatan cantik dan unik. Sejak itu ia mulai tertarik dengan produk Informa, dan mulai membeli perabot di Informa. Fasihah (25 tahun) memiliki pengalaman yang berbeda, ketertarikannya pada Informa berawal ketika ia dan teman-temannya jalan-jalan ke Makassar. Mereka kemudian singgah di mall dan masuk ke Informa. la dan teman-temanya tertarik dengan perabot-perabot yang didisplay. Dinda (30 tahun) mengetahui tentang Informa dari kerabatnya ketika berkunjung ke rumahnya. Sejak itu ia mulai tertarik dan setiap kali membeli perabot ia berbelanja di Informa.

Namun, ada pula yang mengenal Informa pertama kali dari media sosial. Darmi (40 tahun), ia mulai mengenal Informa dari media sosial Facebook jastip dan masingmasing mengamati banyak konsumen yang mengorder, seperti tetangga dan teman kantor, dll. Mereka, sebagaimana tetangga dan temannya, akhirnya tertarik untuk mengisi rumah mereka dengan perabot bermerek Informa. Hal ini hampir sama dengan Purnama (30 tahun), ia mengenal Informa dari teman
Facebooknya yang mengupload barang Informa di postingannya. Berbeda dengan Sri (27 tahun), bahwa ia mengenal Informa dari kerabat kantornya ketika ia berkunjung ke rumahnya dan melihat produk Informa. Dian (24 tahun), mengenal Informa dari keluarganya yang mana ia diperlihatkan salah satu barang Informa.

Informasi tentang keberadaan dan barang jualan Informa menyebar dari mulut ke mulut dan terposting di media-media sosial oleh jastip. Ini membuat orang mulai melirik produk-produk tersebut. Di Bulukumba, meskipun Informa tidak sekedar menjual perabot, namun perabot merupakan barang favorit untuk dibeli. Selain itu, walaupun perabot Informa adalah buatan Cina, produk ini dianggap sebagai "perabot berkelas", sehingga memiliki perabot Informa di dalam rumah mengindikasikan status sosial pemilik rumah. Ini membuat Informa menjadi begitu populer di kalangan ibu-ibu karena membeli perabot identik dengan membeli di Informa. Sejak pandemi Covid-19, penggunaan layanan jastip semakin marak karena mobilitas mereka dibatasi oleh pandemi dan kebijakan pemerintah untuk lebih banyak menghabiskan waktu di rumah ketimbang keluar rumah.

\section{Kenapa Informa Menjadi Pilihan?}

Ada beberapa alasan kenapa Informa menjadi pilihan konsumen, yakni model, display status, harga, dan kualitas produk, sebagaimana yang akan dibahas berikut ini.

\section{Model}

Perabot Informa memiliki disain yang unik, inovatif, dan futuristik, sebagaimana slogannya: "Informa Furnishing with Style". Hal ini menjadi kekuatan dari produk Informa dan menjadi daya tarik tersendiri bagi konsumen. Gambar 1 di bawah ini merupakan salah satu contoh produk perabot yang dijual di Informa. 


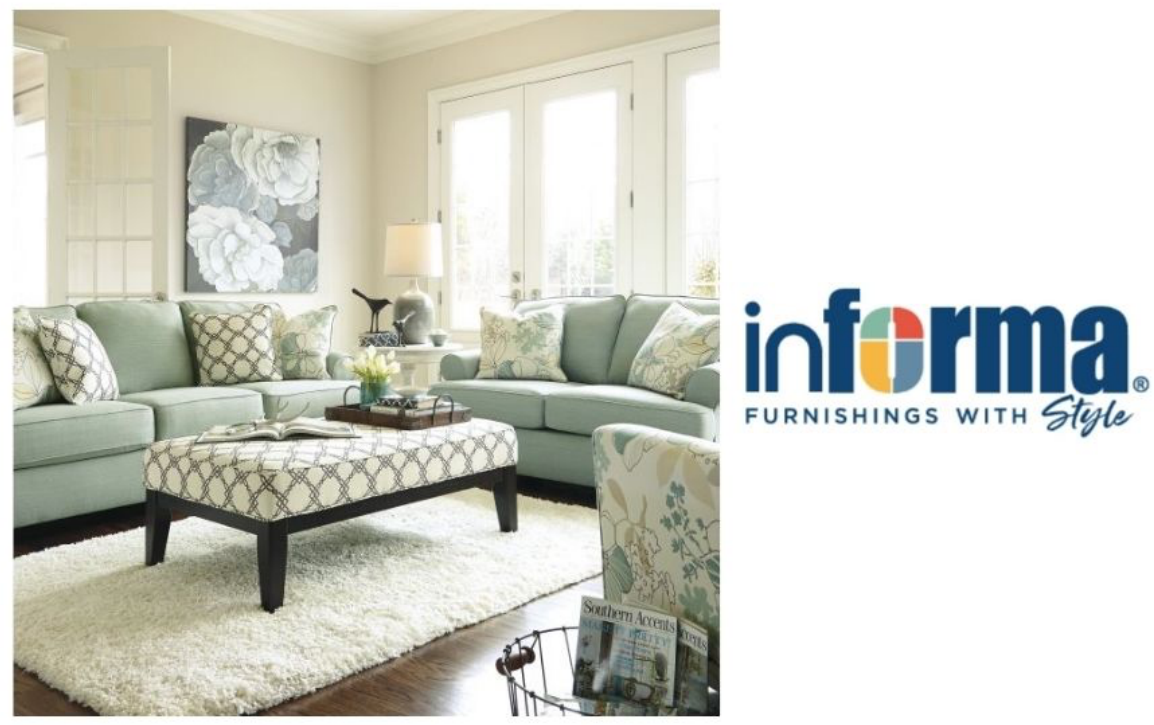

Gambar 1. Contoh produk furnitur Informa

Informa menyediakan berbagai koleksi mulai dari kursi rumah, meja makan, perlengkapan dapur, lampu ruang tamu, hingga perlengkapan yang ditujukan untuk kepentingan yang bersifat komersial. Jika dibandingkan dengan perabot-perabot dengan merek lainnya, maka produk perabot Informa memang menang dari segi disain (model) dengan ruang display yang menarik, sehingga konsumen yang melihatnya juga menjadi tertarik. Berikut kutipan-kutipan informan yang terkait dengan produk perabot Informa.

- "Saya senang berbelanja di Informa karena modelnya yang minimalis dan kekinian. Selain itu, produk Informa identik dengan barang-barang yang unik dan mewah" (Fasihah, 24 tahun).

- "Saya membeli barang Informa, selain karena modelnya yang unik, juga karena modelnya yang kekinian" (Darmi, 40 tahun).

- "Saya tertarik belanja barang Informa karena modelnya yang kekinian dan juga banyak pilihan" (Dian, 24 tahun).
- "Saya sangat senang mengoleksi barang Informa karena memiliki model yang unik dan kelihatan mewah" (Dinda, 30 tahun).

Ulfa (23 tahun) menyatakan bahwa ia suka melihat perabot-perabot rumah. Oleh karenanya ia gemar mengunjungi Informa ketika ia berada di Makassar, dan yang paling sering ditongkronginya adalah di bagian living room. Ini karena ia senang melihat-lihat perabot rumah, seperti sofa, meja tamu, dll., apalagi jika perabotan tersebut berdisain minimalis.

\section{Display Status}

Ibu-ibu rumah tangga cenderung berbelanja di Informa karena dianggap sebagai "barang yang berkelas", sehingga orang yang memilikinya dianggap sebagai "orang yang berkelas". Sri (27 tahun) mengungkapkan, bahwa produk perabot dengan merek tertentu seperti Informa ini yang tidak bisa didapatkan di daerahnya, sehingga untuk mendapatkannya, orang harus ke Makassar. Di kalangan ibu-ibu, membeli perabot di Bulukumba "beda kelas" dengan membeli perabot di Makassar, terutama merek Informa yang sedang tren di 
Bulukumba. Oleh karenanya, memiliki perabot Informa di dalam rumah adalah simbol yang mendisplay status pemiliknya.

Ulfa (23 tahun) mengungkapkan bahwa ia memang menyukai barang-barang Informa. Rata-rata barang di rumahnya adalah keluaran Informa karena ia tidak mau kalah dengan tetangganya yang memiliki perabot merek Informa. Sekarang dengan adanya jastip, ia tidak usah lagi keluar rumah, tinggal menunggu barang diantarkan. Saat barang pesanannya diantarkan, otomatis tetangga melihat apa yang dibelinya. Pentingnya menunjukkan bahwa barang belanjaannya adalah produk Informa menjadi masuk akal ketika Darmi (40 tahun) juga menyampaikan hal serupa bahwa ia juga tidak mau kalah dengan merek perabot tetangganya yang dibeli yakni Informa, meskipun barang-barang tersebut dibelinya secara angsuran (cicil) melalui penyedia jastip. Ini menunjukkan bahwa produk Informa telah menjadi simbol status bagi pemiliknya. Hampir sama dengan Dian (24 tahun) mengungkapkan bahwa ia mengisi perabot rumahnya dengan barang Informa karena tidak mau kalah saing dengan keluarganya maupun teman-temannya yang memiliki barang Informa. Ini juga di ungkapkan Fasihah (30 tahun) bahwa memiliki perabot rumah tangga merek Informa adalah suatu kebanggaan bagi diri sendiri ketika keluarga dan teman berkunjung ke rumah bisa melihat bahwa rumahnya di penuhi dengan koleksi Informa.

Terkadang ada pula barang Informa yang modelnya mirip dengan produk dengan merek lain, dengan harga yang lebih murah, dan dijual di toko perabot di Kabupaten
Bulukumba, namun orang lebih memilih untuk membeli barang Informa. Hal ini dikarenakan adanya citra sebuah merek. Bagi masyarakat Bulukumba khususnya yang sudah tau model dan bentuk perabot-perabot Informa, jika bertamu ke rumah suatu keluarga dan perabotnya adalah perabot yang dibeli di Informa, maka ini menunjukkan status sosial pemilik rumah.

\section{Harga}

Harga selalu menjadi perhatian bagi ibu-ibu yang ingin berbelanja. Ada frasa yang seringkali didengar baik di kalangan ibu-ibu, maupun bapak-bapak, bahwa "Bukan ibu-ibu namanya kalau tidak nawar atau diskon", sehinga mereka sangat jeli melihat harga barang dan barang apa yang didiskon.

Harga perlengkapan di Informa sangat beraneka ragam, tergantung jenis barang, apakah barang baru (new arrival) atau barang yang sudah lama yang biasanya mendapatkan potongan harga (discounted price), bahkan hingga 70 persen (lihat Gambar 2). Meskipun demikian, sejumlah seri produk furnitur berharga cukup tinggi. Oleh karenanya, berbelanja saat promosi (promo) atau diskon sangat menguntungkan bagi pembeli.

Menurut Darmi (40 tahun), ia sangat tertarik berbelanja melalui jastip ketika mengadakan promo. Harganya yang sangat jauh dari harga sebelumnya. Hal ini serupa dengan Sri (27 tahun), yang mengungkapkan bahwa ia senang berbelanja jastip Informa karena sering mengadakan diskon. Dan kadang pula mendapatkan bonus. Ini membuatnya merasa untung karena harganya yang jauh berbeda dengan harga normalnya. 

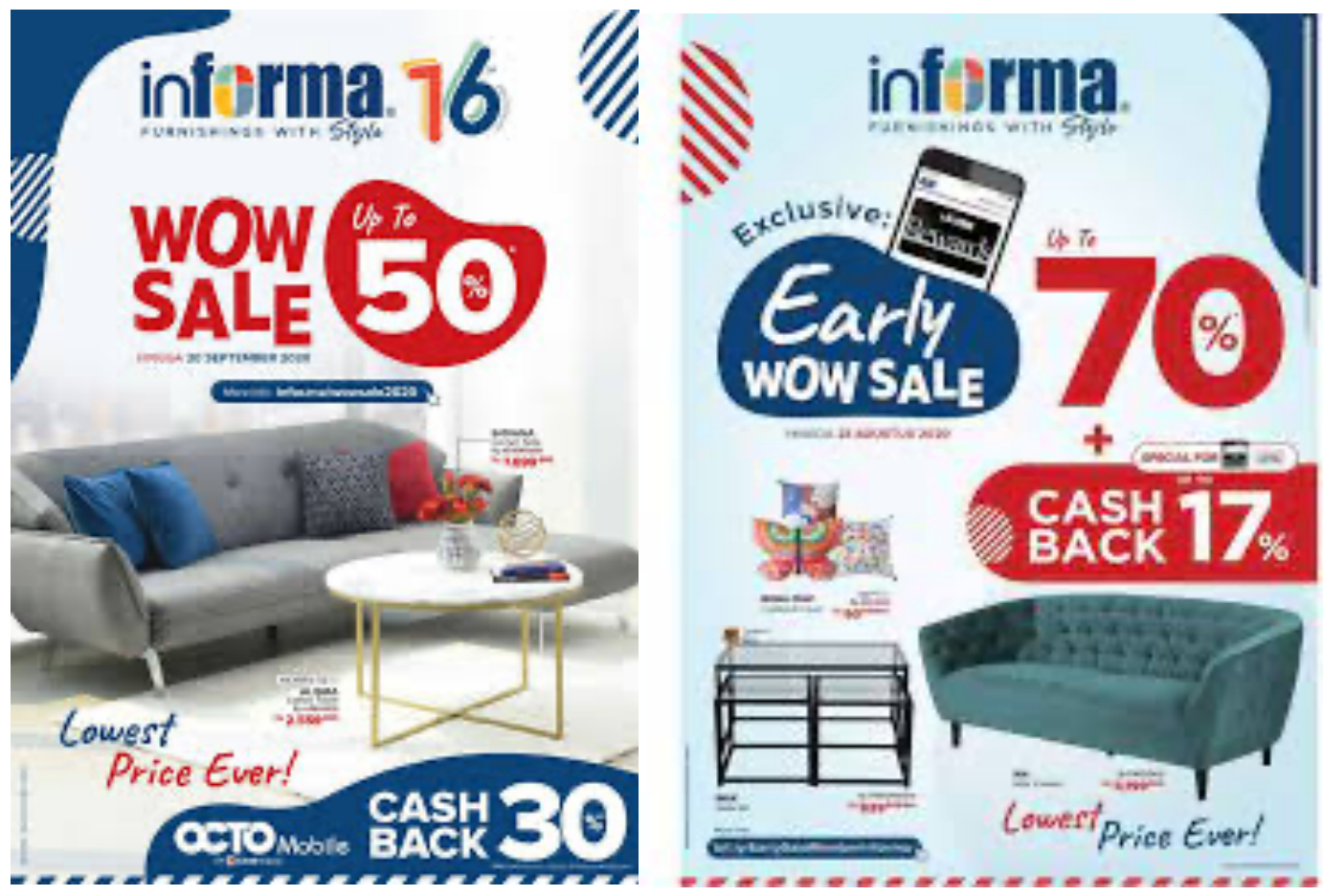

Gambar 2. Produk perabot sale

Menurut Ulfa (23 tahun), berbelanja perabot melalui penyedia jastip Informa dapat menyesuaikan dengan isi dompet. Harga barang bervariasi dari harga ratusan ribu hingga jutaan rupiah. Selain itu ongkos ke toko pun berkurang, walaupun ada biaya jastipnya tapi tidak sebanding ketika ia datang langsung di toko. Orang yang berbelanja melalui jastip Informa tinggal memilih barang dirumah melalui sosial media (Facebook) dengan harga yang sesuai dengan kemampuan masingmasing.

Pelanggan jastip lainnya, Purnama (30 tahun), yang juga mengatakan hal serupa, dengan mengungkapkan pengalamannya membeli kursi melalui jastip saat sedanga ada diskon dengan harga Rp3.000.000, padahal harga aslinya Rp3.500.000. Di masa pandemi Covid-19, berbelanja melalui penyedia layanan jastip memiliki keuntungan berganda, tidak menguras waktu dan tenaga untuk ke toko, dan harga diskon pun tetap masih dapat diperoleh. Menurut Fasihah (25 tahun), oleh karena ia takut bepergian di masa pandemi Covid-19, maka ia memilih berbelanja melalui jastip karena menurutnya harganya relatif lebih murah ketika ada promosi (promo) khusus.

\section{Kualitas}

Kualitas biasanya berkelindan dengan harga. Ada frasa yang seringkali terdengar bahwa "harga tidak berbohong", yang bermakna bahwa jika suatu barang berkualitas, maka harganya juga berkualitas (mahal). Tapi dalam kaitan dengan produk perabot Informa, frasa tersebut tidak selalu berbanding lurus.

Bagi mereka yang terbiasa berbelanja di Informa, mereka telah menyikapinya dengan berbelanja pada saat ada promosi/diskon, sehingga mereka tetap dapat berbelanja barang berkualitas dengan harga promo/diskon. Para pelayan toko juga rajin menginformasikan melalui media sosial Whatsapp kepada pelanggan tentang barangbarang apa saja yang sedang promo/diskon, sehingga informasi tersebut selalu up to date. Bahkan karena terlalu seringnya memosting di Whatsapp, sehingga terkadang membuat pelanggan menjadi terganggu karena "memberatkan" hape mereka. 
Menurut Purnama (25 tahun) kualitas barang Informa sebanding dengan harganya karena sejauh ini cukup bagus ketahanannya cukup lama dan tidak mudah rusak. Biasanya meja makan merek biasa itu kalau sudah lama kayunya atau serbuk-serbuknya sudah berjatuhan. Menurut Sri (27 tahun) bahwa barang Informa memiliki kualitas yang bagus ia tidak merasa rugi mengoleksinya. Ini juga diungkapkan Fasihah (25 tahun) ia senang mengoleksi barang Informa karena kualitanya bagus dan menurutnya antara kualitas dan harga sebanding. Hal inilah yang membuat ia senang membeli barang Informa.

\section{Eksistensi Layanan Jastip}

Di Indonesia istilah jastip mulai banyak dikenal oleh masyarakat luas khususnya bagi mereka yang menggunakan media sosial seperti Facebook. Jastip merupakan layanan informal yang menawarkan bantuan kepada orangorang yang membutuhkan atau ingin membeli sesuatu tetapi tidak dapat pergi ke tempat yang diinginkan untuk membeli sendiri karena berbagai alasan, seperti mengurangi waktu dan tenaga untuk antri panjang.

Jastip bukan hal baru bagi ibu-ibu di Kabupaten Bulukumba, demikian halnya dengan penggunaan layanan jastip tersebut. Meskipun ada banyak penyedia layanan jastip, namun @jastipbyarumi merupakan salah satu di antara banyak penyedia layanan jastip yang populer di kalangan ibu-ibu di Kabupaten Bulukumba.

Penyedia layanan jastip dengan akun bernama @jastipbyarumi adalah milik Umi (23 tahun). la dulunya seorang honorer di Kantor Pemerintah Daerah Kabupaten Bulukumba. Namun, prospek sebagai penyedia layanan jastip yang semakin digemari masyarakat, terutama di kalangan ibu-ibu membuatnya akhirnya mengambil keputusan untuk sepenuhnya menekuni profesi independen ini.

Awalnya, ini hanya menyediakan layanan jastip karena iseng-iseng, tapi kemudian peminatnya ternyata banyak di Kabupaten Bulukumba dimana dia berdomisili. la memulai dengan menjual pakaian. Tapi kemudian seiring dengan banyaknya peminat barang Informa, ia akhirnya memokuskan bisnisnya pada jastip peralatan rumah tangga bagi kalangan ibu-ibu di Kabupaten Bulukumba yang senang berbelanja online dan sebagai peluang usaha, memuaskan hobi serta menambah pemasukan apalagi ditengah masa pandemi Covid-19 demi mempertahankan hidup.

la tidak menyangka, bahwa kesibukan yang dilakoninya semenjak dua tahun lalu ini, kini dapat mendatangkan order hingga senilai Rp30 juta/bulan. Konsumennya pun tidak hanya datang dari Kabupaten Bulukumba, tetapi juga dari berbagai kabupaten tetangga, seperti Kabupaten Sinjai, Bantaeng, Jeneponto, hingga Gowa yang merupakan kabupaten tetangga dari Makassar, ibukota Sulawesi Selatan.

Umi pun tidak membatasi jumlah titipan. Untuk barang yang tergolong laris, ia biasanya membeli lebih banyak untuk disimpan (stok) sementara di rumahnya, seperti sofa bed, kursi teras, hiasan dinding, meja makan. Berbelanja di Informa menjadi bagian dari rutinitasnya sebagai penyedia layanan jastip. la memiliki jadwal berbelanja ke Informa hingga empat kali kali dalam seminggu, yakni hari Senin dan Kamis, serta hari Jum'at dan Sabtu. Meskipun terkadang ia capek, namun karena pada dasarnya ia tipe orang yang senang belanja, sehingga ia melakoni pekerjaan ini dengan santai dan selama ini ia juga dibantu oleh suaminya. la memiliki filosofi dalam bisnis jastip: "Sambil jalan-jalan dapat uang".

Masyarakat, menurut Umi (23 tahun), sekarang sudah terbiasa dengan hal-hal yang simpel, hingga berbelanjapun disimpelkan (baca: dibelanjakan oleh orang lain). Oleh karenanya keberadaan jastip menjadi sangat signifikan karena mereka tidak perlu kemanamana dan barang yang dibeli tiba di rumah. 
Selain kemudahan tersebut, bagi para pelanggan, jastip juga digemari karena dianggap menguntungkan. Mereka bisa mendapatkan barang-barang yang tidak ada di daerahnya dan kadang dengan harga yang lebih murah barang yang diinginkan sedang promo/diskon atau mereka berbelanja ketika ada promo/diskon.

Waktu yang terbatas saat berkunjung ke pusat penjualan furnitur Informa di Makassar membuat Ulfa (23 tahun) merasa tidak puas. la pun segera mengalihkan hasratnya ke media sosial mencari katalog produk Informa. Bukan hanya katalog produk Informa yang ia dapatkan, melainkan juga akun Facebook milik Umi (23 tahun), yang menyediakan jastip pembelian produk Informa. la akhirnya menjadi langganan layanan jastip @jastipbyarumi.

Menurut Ulfa (23 tahun), jika berbelanja melalui jastip ada biaya tambahan dari jasa dan biaya pengiriman, tapi dia merasa biaya tambahan itu wajar-wajar saja karena Informa tidak ada di daerahnya. Dengan menggunakan jastip juga direspon secara cepat dan penyedia jasanya yang juga ramah, sehingga membuatnya merasa nyaman berbelanja. Ulfa mengungkapkan bahwa meskipun Informa sering mengadakan sale, ia tidak lagi mengikuti perkembangannya secara langsung di toko Informa sejak ia mengenal jualan online dengan layanan jastip di Facebook. Bagi Sri (27 tahun), selama pandemi Covid-19, layanan jastip sangat bermanfaat, meskipun ada pengeluaran tambahan untuk jastip-nya, dan biaya pengiriman yang harus ditanggung oleh pembeli. Namun, ini tidak masalah karena tanpa keluar rumah, ia dapat memeroleh barang yang dibeli melalui jastip. Hal serupa ditegaskan oleh Purnama (30 tahun), bahwa biaya jastip dan ongkos kirim (ongkir) lebih murah dibandingkan jika pergi ke Informa untuk membeli langsung. Apalagi di masa pandemi ini, ia bukan saja menghabiskan waktu di rumah karena PSBB, tapi ia juga memang malas ketemu orang di masa pandemi.

Namun, Purnama menyarankan untuk selektif memilih penyedia layanan jastip untuk menghindari penipuan. Purnama sejauh ini berlangganan dengan penyedia jastip @jastipbyarumi yang menurutnya terpercaya, cepat merespon, dan ramah terhadapnya. Peringatan serupa juga disampaikan oleh Darmi (40 tahun), yang sudah sering menggunakan layanan jastip dan sangat selektif memilih jastip. la hanya mau berbelanja melalui penyedia jastip yang telah ia kenal sebelumnya dan telah menjadi langganannya.

Menurut Ulfa (23 tahun), peran layanan jastip sangat signifikan bagi dirinya yang bekerja dan sebagai ibu rumah tangga. la tidak memiliki banyak waktu untuk khusus datang ke Makassar. Layanan jastip membantunya untuk menghemat waktu, tenaga, dan biaya. Keuntungan lainnya, berbelanja dengan menggunakan layanan jastip dibandingkan toko online tanpa jastip adalah ada interaksi antara pembeli dan penyedia layanan jastip tentang barang yang akan dipesan (seperti warna, ukuran, jumlah, dll.), baik melalui media sosial maupun interaksi tatap muka.

Jauh sebelum bisnis jastip pada 2015, Umi sudah menggeluti dunia bisnis. Dalam perjalanannya, jastip dimudahkan lewat kehadiran media sosial, terutama Facebook. la memanfaatkan Facebook untuk meraih calon pembeli dengan menggunakan akun pribadinya. Yang mana akun pribadi adalah akun yang tidak dapat dipisahkan antara akun personal dan akun promosi jastip sehingga ia merasa mudah untuk mempromosikan jasanya. Dalam mempromosikan jasanya ada berbagai macam strategi yang digunakan, mulai dari mengadakan promo (diskon), mengunggah produk di story, membuka lot arisan barang serta mengandalkan status WhatsApp mereka untuk menyebarkan 
penawaran jastip. Melihat barang Informa yang berkualitas, dirinya terpincut untuk berjualan. Lalu la melakukan pencarian di internet untuk mencari produk-produk Informa. Ketika mengecek harganya di internet, yang muncul justru jasa titip. Setelah mempelajari secara teliti, saya kemudian merminat untuk membuka layanan jastip. Dia juga bertemu teman lamanya yang bekerja sebagai jastip di Informa, yang semakin membuatnya percaya diri untuk melakukannya.

Menurutnya, ada perbedaan antara jastip dan berjualan baju online shop. Jika online shop konsumen tidak mengetahui harga asli sebuah produk, jastip justru sebaliknya. Konsumen mengetahui harga asli produk dan bayaran untuk jasa titipnya. Semuanya benarbenar transparan. Pembeda lainnya adalah dalam proses pembelian hingga sampai ke tangan konsumen. Jika berjualan baju, setelah dibeli tinggal dimasukkan ke tas plastik dan selesai, maka penjualan melalui jastip, penjual harus beli barang dulu di toko, lalu dikemas sendiri sebelum dikirim ke konsumen. Yang merepotkan penyedia layanan jastip dalam pengemasan adalah karena barang-barang yang dibeli (dari Informa) umumnya besar. Tapi menjual barang-barang kecil seperti barang pecah belah cukup beresiko dalam proses pengantaran, dan itu menjadi alasannya kenapa ia berfokus pada perabot (lihat Gambar 2).
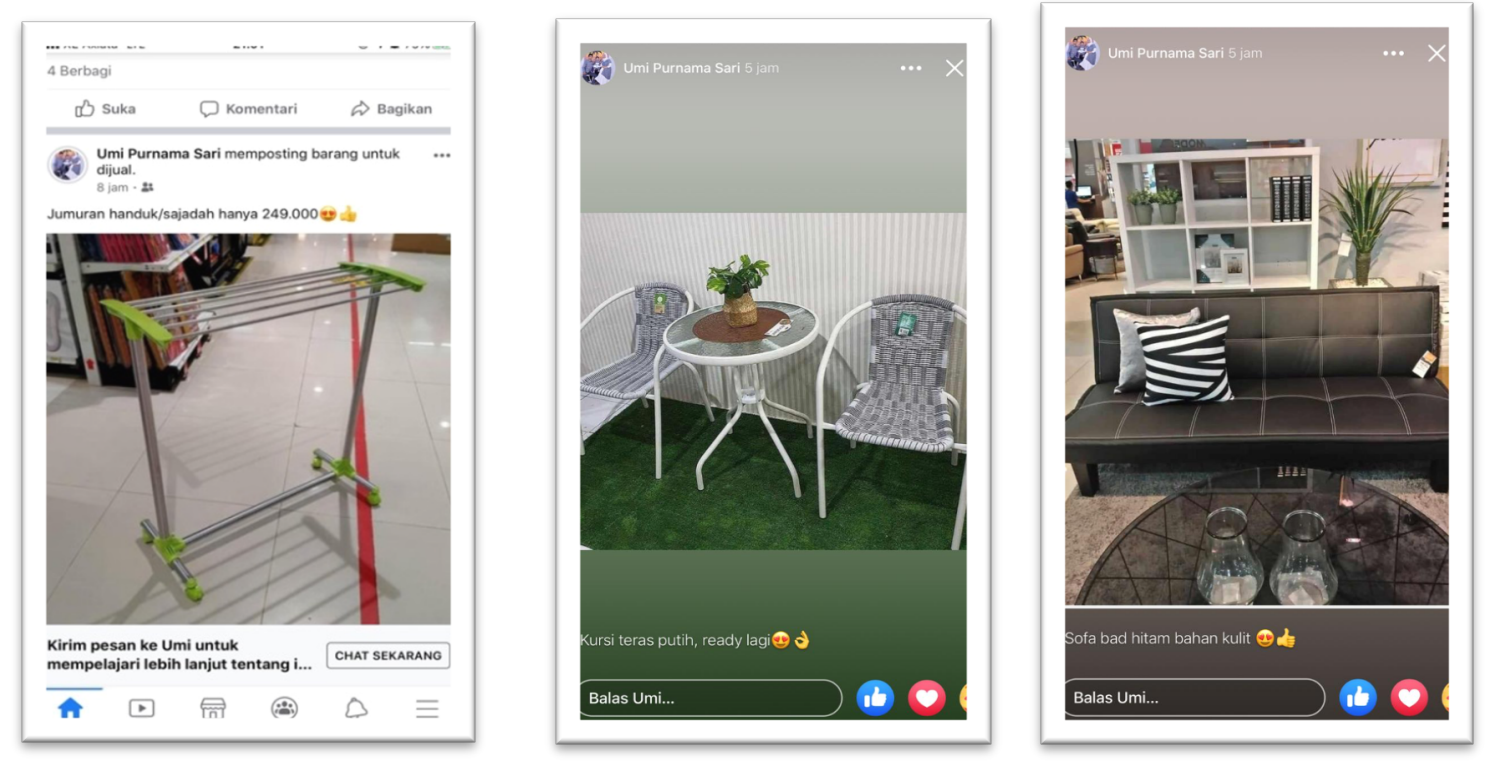

Gambar 2. Postingan Akun @jastipbyarumi

Bergerak di bisnis jasa ini, modal utamanya bukanlah uang melainkan kepercayaan, ketekunan, dan etika bisnis dalam menjalankan bisnis ini. Sebagai penyedia layanan jastip, Umi harus rajin pergi ke toko untuk update harga dan produk. Berdasarkan pengalaman dirinya, yang memang memulai bisnis jastip tanpa modal besar, cukup dengan memiliki telfon pintar (smartphone) untuk memotret produk dan diposting di media sosial, seperti Facebook, serta berkomunikasi dengan konsumen melalui Whatsapp. Untuk pembelian barang, ia dimodali oleh pembeli karena pembeli harus membayar melalui transfer sebelum barang dikirimkan, dan pembayaran itu mencakup harga barang, biaya layanan jastip, dan ongkir. Namun, ia juga dapat melayani mereka yang memesan barang dengan pembayaran yang dilakukan setelah barang diterima (COD, cash on delivery). 
Dengan pekerjaan sebagai penyedia layanan jastip, Umi mendeskripsikan dirinya sebagai penyedia jastip yang cukup berhasil karena dari pekerjaan itu ia telah memiliki mobil pribadi dan hidup sejahtera paling tidak menurut indikator pribadinya.

\section{Omzet Jastip di Masa Pandemi Covid-19}

Pandemi Covid-19 merupakan wabah yang tidak hanya dirasakan Indonesia, tetapi juga berbagai negara yang ada di dunia. Dalam beberapa bulan saja wabah ini mematikan berbagai sektor kehidupan manusia termasuk sektor perekonomian, yang merupakan elemen penting untuk berkontribusi sebagai sarana pemasukan suatu negara (Mahriani 2020:12).

Pandemi Covid-19 membuat pergerakan masyarakat menjadi terbatas. Hal ini membuat sejumlah orang semakin mengandalkan aktivitas secara online, termasuk jual-beli online. Mekipun demikian jastip bukanlah sesuatu yang baru atau kemunculannya baru pada saat pandemi. Namun, penggunaan layanan jastip menjadi semakin intensif di masa pandemi Covid-19 karena konsumen dapat berbelanja tanpa harus keluar rumah, terutama karena ada kebijakan PSBB.

Ketika kebijakan PSBB mulai diberlakukan, banyak toko dan restoran yang mulai membatasi jam operasi, dari pusat perbelanjaan, toko retail, hingga restoran mengurangi aktivitas mereka. Hal ini bak angin segar bagi penyedia layanan jastip karena orang lebih banyak menghabiskan waktu di rumah, namun hidup tetap harus dilanjutkan.

Menurut Umi (23 tahun), di awal pandemi Covid-19 (Maret 2020) orang masih belum mengetahui bagaimana bersikap menghadapi pandemi tersebut. Saat itu orang belum mulai berbelanja. Namun, pada bulan April 2020 hingga sekarang, pesanan semakin lama semakin meningkat. Tren belanja melalui layanan jastip perlahan telah menjadi kebiasaan baru selama pandemi, khususnya bagi para ibu-ibu.

Umi menawarkan barang-barang Informa melalui Facebook. Selanjutnya, jika ada yang tertarik dengan barang tersebut, maka komunikasi dilanjutkan melalui messenger Facebook, atau Whatsapp. Konsumen juga dapat memesan barang yang diinginkannya secara langsung kepada Umi melalui dua personal message dari media sosial, tergantung pada jenis media sosial apa yang digunakan oleh konsumen yang menjadi alat komunikasi di antara Umi dan konsumen.

Sejak bergelut dengan produk Informa, Umi telah memiliki kedekatan dengan pihak retail Informa dan beberapa karyawannya. Ini membuat informasi tentang barang-barang Informa terbaharui (updated), hampir setiap hari, terutama yang terkait dengan berbagai harga spesial yang ditawarkan oleh Informa. Pihak retail bahkan merasa terbantu dengan eksistensi layanan jastip karena di masa pandemi Covid-19 ketika penjualan menurun drastis karena PSBB, jastip menjadi "juru selamat" yang membantu dalam penjualan barang-barang Informa.

Menurut Umi, puncak pemesanan terjadi pada September 2020. Umi memperkirakan total permintaan mencapai 1.000 pesanan dengan pemasukan dari layanan jastip sebesar belasan juta rupiah. Kursi teras yang terbuat dari kayu merupakan barang yang terpopuler yang dipelanggan Umi bukan saja mereka yang membeli untuk pemakaian sendiri, tapi reseller barang Informa juga masuk dalam daftar anggotanya. Oleh karenanya, jika pada masa pandemi orang mengalami krisis, di PHK, sehingga pemasukan bukan saja berkurang bahkan hilang sama sekali, penyedia jastip seperti Umi justru mendulang keuntungan.

Biaya jastip untuk setiap barang yang dibeli oleh konsumen adalah antara Rp20.000,dan Rp35.000,-, tergantung harga barang. Semakin mahal harga barangnya, semakin 
tinggi biaya jastipnya. Jika dalam seminggu ia mendapatkan 50 pesanan, maka ia akan mendapatkan pemasukan sebesar antara Rp1.000.000,- dan Rp1.750.000,-. Untuk ongkos kirim (ongkir) tergantung dari bentuk dan tingkat kesulitan pengemasan barang tersebut. Misalnya, untuk perabot seperti sofa, pengemasannya cukup besar, sehingga ongkirnya juga lebih mahal (antara Rp50.000dan Rp100.000-) jika dibandingkan dengan barang seperti jam dinding, bantal (kursi, kepala, guling) yang ongkirnya lebih murah (antara Rp20.000- dan Rp30.000-), tergantung jumlah (antara Rp2.000.000- dan Rp5.000.000) item yang dibeli, semakin banyak, semakin mahal (lihat Gambar 2 berikut ini).

Selain dapat menghasilkan omzet belasan jutaan rupiah, bisnis jastip ini memiliki keuntungan lain, seperti mendapatkan poin tambahan dari kartu kredit karena sering menggunakannya untuk berbelanja, mendapatkan bonus barang, menjadi member Informa, mendapatkan keuntungankeuntungan lainnya (seperti voucher belanja, potongan harga, hingga paket liburan).

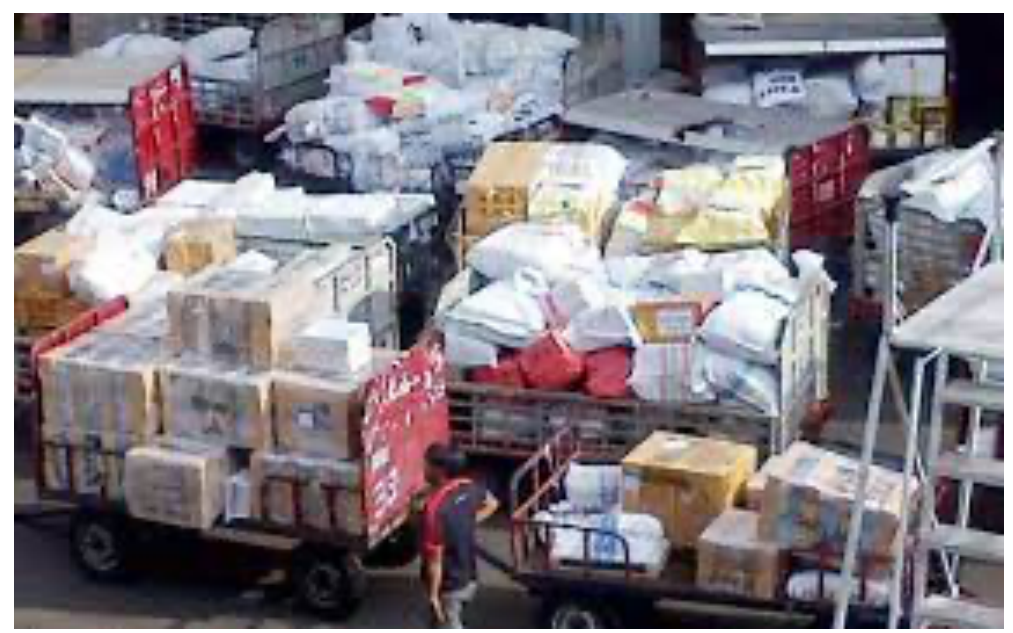

Gambar 2. Postingan barang yang telah dikemas

Namun, bergelut dalam dunia jastip juga memiliki sisi pahitnya. Meskipun Umi kebanyakan melademi pemesanan yang pembayarannya dilakukan sebelum barang diterima (prepaid), ia juga melayani pemesanan dengan sistem pembayaran setelah barang diterima (cash on delivery). Namun, sistem pembayaran seperti ini cukup berisiko jika barang sudah dibeli, tapi pemesannya membatalkan sepihak dengan alasan yang beragam, seperti mengingkari pemesanan, membatalkan pemesanan, atau karena suami terkena pemutusan hubungan kerja (PHK) sebagai imbas dari pandemi Covid19. Jika menemukan kasus seperti itu, Umi tak segan mengeluarkan orang tersebut dari grup Whatsapp member dan memblokirnya karena dianggapnya mengganggu kestabilan finansial bisnis jastip yang digelutinya.

\section{Kesimpulan}

Fenomena jastip merupakan model bisnis yang memiliki potensi untuk dikembangkan yang didukung oleh perkembangan teknologi, dan media sosial dijadikan sarana untuk berjualan secara online dengan layanan jastip. Adanya layanan jastip di masa pandemi Covid-19 sangat menguntungkan baik bagi pihak penyedia jastip @jastipbyarumi maupun konsumennya.

Temuan penelitian ini menunjukkan bahwa jastip produk Informa menjadi pilihan di kalangan ibu-ibu yang dibeli secara online melalui layanan penyedia jastip yang diposting 
melalui media sosial Facebook. Diantara barang-barang jastip lainnya di Facebook, perabot rumah tangga (sofa, meja makan, kursi teras, dII) adalah barang yang paling populer. Model, display status, harga dan kualitas merupakan empat alasan utama mengapa perempuan memilih jastip produk Informa. Adapun alasan bagi penyedia jastip @jastipbyarumi menghadirkan layanan jastip produk Informa adalah karena ibu-ibu di Kabupaten Bulukumba senang berbelanja online sehingga dilihat sebagai peluang usaha, memuaskan hobi, serta sebagai sumber pendapatan. Dalam memromosikan layanan jastip, maka strategi yang digunakan oleh penyedia layanan jastip (@jastipbyarumi adalah tetap memberikan harga diskon toko, mengunggah produk di story, dan membuka lot arisan barang. Bergerak di bisnis jasa ini, modal utamanya bukanlah uang semata, melainkan kepercayaan, ketekunan, dan etika dalam menjalankan bisnis ini. Peningkatan penggunaan jastip selama pandemi Covid-19 berkelindan dengan peningkatan omzet jastip (@jastipbyarumi).

\section{Daftar Pustaka}

Artaya, I P. dan Baktiono, R. A. 2016. "Memilih Media Sosial Yang Efektif Sebagai Sarana Marketing Online Bagi Pelaku UKM di Kabupaten Sidoarjo", E-Jurnal Spirit Pro Patria, 2(2):8-21, diakses tanggal 28 desember 2020.

Elisa. 2018. Tinjauan Hukum Islam Terhadap Jasa Titip pada Praktik JualBeli Online.Skripsi, Fakultas Syariah dan Hukum, Universitas IslamNegeriKalijaga Yogyakarta, Yogyakarta, http://digilib.uinsuka.ac.id/30494/, diakses tanggal 11 Januari 2021.

Laohapensang, O. 2009. "Factors Influencing Internet ShoppingBehaviour: A Survey Of Consumers In Thailand", Journal of
FashionMarketingAnd Management, 13(14):501-513,

https://www.emerald.com/insight/pu blication/issn/1361-2026, diakses tanggal 7 Januari 2021.

Mahriani, E. 2020. “Model Bisnis di Tengah Pandemi Covid-19", Jurnal Hadartul Madaniya, Juni, 7(1):9-14, http://journal.umpalangkaraya.ac.id/i ndex.php/ihm/article/view/1596, Diakses tanggal 10 Maret 2021.

Mahesti, I. P, dan Gusti. 2019. “Perlindungan Hukum Terhadap PenggunaJasa TitipOnline", Journal Ilmu Hukum, November, $\quad 7(10): 1-$ 17,https://ojs.unud.ac.id/index.php/K erthanegara/article/download/54596/ 32341, diakses tanggal 10 Maret 2021.

Muslicha, I. S, dan Irwansyah. 2019. "Instagram dan Fenomena Jastip di Indonesia", Journal Communication Spectrum, 9(1):143-157, http://jurnal.bakrie.ac.id/index.php/Jo urnal Communication spectrum/, diakses tanggal 7 Januari 2021.

Nasution, D.A.D.; Erlina; dan Muda, I. 2020. "Dampak Pandemi Covid-19 Terhadap Perekonomian Indonesia", Jurnal Benefita, Juli, 5(2):212-224, http://ejournal.Ildikti10.id/index.php/ benefita/article/download/5313/1812 , diakses tanggal 28 Mei 2021.

Pusparisa, Y. 2020. E-Commerce Tumbuh di Tengah Pandemi Covid19", https://katadata.co.id/ariayudhis tira/infografik/5ec48b7f099d1/ecommerce-tumbuh-di-tengahpandemi-covid-19, diakses tanggal 18 Juni 2021.

Putra, M. 2018. Efektivitas Media Sosial Instagram Sebagai Media Komunikasi Pemasaran: Studi Kasus pada Online 
Shop@siramah_jogja. Skripsi, Program Studi Manajemen, Fakultas Ekonomi, Universitas Sanata Dharma, Yogyakarta.

Rizki, D. A. 2020. Tinjauan Hukum Ekonomi Syariah Terhadap Akad Jasa Titip Jual Beli Online Melalui Instagram: Studi Kasus Toko Online JoyfullDi Purwokerto). Skripsi, Fakultas Syariah, Institut Agama Islam Negeri Purwokerto, Purwokerto, http://repository.iainpurwokerto.ac.id 8043/2/Della\%20Rizki\%20Amanda Ti njauan\%20Hukum\%20Ekonomi\%20Sy ariah\%20Terhadap\%20Akad\%20Jasa\% 20Titip\%20Jual\%20Beli\%200nline\%20 Melalui\%20Instagram\%20Studi\%20Ka sus\%20Toko\%200nline\%20Joyfull\%20 di\%20Purwokerto.pdf, diakses tanggal 10 Maret 2021.

Rizki, A. P. 2019. Pola Komunikasi Antara Penyedia Jasa Titip Beli (Jastip) Denga Konsumen Dalam Berbelanja Melalui Instagram (Studi Pada Pola Komunikasi Jasti@Herhabit.Jastip Dengan
Konsumennya). Skripsi, Fakultas IImu Sosial dan Ilmu Politik, Universitas Sriwijaya, Palembang.

Sari, Z. D. 2018. Analisis Fiqih Muamalah Terhadap Praktik Jasa Titip Online di Akun Instagram @Storemurmersby. Skripsi, Fakultas Syariah dan Hukum, Universitas Islam Negeri Sunan Ampel Surabaya,

Surabaya,http://digilib.uinsby.ac.id/27 655/1/Zurifah\%20Diana\%20Sari C022 14027.pdf, diakses tanggal 10 Februari 2021.

Tjiptono, F dan Chandra. 2012. Pemasaran Global Konteks Offline dan Online. Yogyakarta: UPP STIM YKPN.

Wariati, A, dan Nani I. S. 2014. "E-commerce Dalam Perspektif Perlindungan Konsumen", Jurnal Ekonomi \&Bisnis, November, $\quad 1(2): 1-19$. https://media.neliti.com/media/publi cations/162105-ID-none.pdf, diakses tanggal 9 Maret 2021. 